\title{
Influence of land-use on structural and functional macroinvertebrate composition communities associated on detritus in Subtropical Atlantic Forest streams
}

Influência do uso da terra sobre a composição estrutural e funcional da comunidade de macroinvertebrados associados a detritos em riachos subtropicais da Floresta Atlântica

Luiz Ubiratan Hepp ${ }^{1}$, Frederico Machado Urbim르 Gabriela Tonello ${ }^{1}$, Rafael Chaves Loureiro ${ }^{1}$, Tanise Luisa Sausen ${ }^{1}$, Rodrigo Fornel ${ }^{1}$ and Rozane Maria Restello ${ }^{1 *}$

${ }^{1}$ Programa de Pós-graduaçáo em Ecologia, Universidade Regional Integrada do Alto Uruguai e das Missões - URI, Avenida Sete de Setembro, 1621, CEP 99709-910, Erechim, RS, Brazil *e-mail: rrozane@uricer.edu.br

Cite as: Hepp, L.U. et al. Influence of land-use on structural and functional macroinvertebrate composition communities associated on detritus in Subtropical Atlantic Forest streams. Acta Limnologica Brasiliensia, 2016, vol. 28, e3.

Abstract: Aim: Our aim in this study was to evaluate the effects of land use in drainage basins of the streams on the taxonomic and functional composition of aquatic invertebrate communities associated in leaf litter. Methods: We evaluated the colonisation of invertebrates in the incubated plant debris in streams with presence and absence of riparian vegetation and different land-uses in the drainage area. We used the litter bags approach. Results: The taxonomic and functional composition invertebrate associated with leaf litter ranged between streams. In addition, streams with presence of vegetation showed less variation taxonomic and functional composition communities. Still, the density of shredders invertebrates were lower in streams without vegetation. Conclusions: The riparian vegetation is an important environmental factor in the composition of invertebrates. However, the land-use throughout the drainage basin should be considered as relevant factor in structuring aquatic biota.

Keywords: invertebrates colonisation; functional feeding group; environmental quality; environmental integrity.

Resumo: Objetivo: O objetivo deste estudo foi avaliar os efeitos de usos da terra em bacias de drenagem de riachos sobre a composição taxonômica e funcional das comunidades de invertebrados aquáticos associados a detritos foliares. Métodos: Avaliamos a colonização de invertebrados em detritos de plantas incubadas em riachos com presença e ausência de vegetação ripária e diferentes usos da terra na área de drenagem. Utilizamos a abordagem de litter bags. Resultados: A composiçáo taxonômica e funcional da fauna de invertebrados associados aos detritos variou entre os riachos. Além disso, os riachos com presença de vegetação mostraram comunidades com menor variação taxonômica e funcional. Ainda, a densidade de invertebrados fragmentadores foi menor nos riachos sem vegetação. Conclusôes: A porcentagem de vegetação ripária é um fator ambiental importante na composição dos invertebrados. Porém, os usos da terra em toda a bacia de drenagem devem ser considerados como fatores relevantes na estruturação da biota aquática.

Palavras-chave: colonização de invertebrados; grupos tróficos funcionais; qualidade ambiental; integridade ambiental. 


\section{Introduction}

Agricultural activities have increased the degradation of forests in recent decades (Carvalho et al., 2009; Diniz-Filho et al., 2009). When natural riparian vegetation is removed for agricultural uses, the water temperature, nutrient concentration and sediment input tend to increase in streams, causing negative effects to the ecological integrity of aquatic ecosystems (Allan, 2004; Blevins et al., 2013). However, it is unclear how the combined effect of different anthropogenic factors (e.g., riparian vegetation removal) can alter ecological processes and aquatic biota (Hagen et al., 2006; Arnaiz et al., 2011; Bonato et al., 2012; Chadwick et al., 2012).

Riparian zones are important for the maintenance and regulation of the aquatic environment (Naiman et al., 2005). The presence of riparian vegetation acts as a barrier to sediment input (Klapproth \& Johnson, 2000), performing a hydrological role (e.g. superficial filtering effect and sub-surface water) and assisting in water quality maintenance. The removal of riparian vegetation in agricultural areas causes the loss of allochthonous material input, which is of key importance for maintaining the energy flow and balance of streams (Henry et al., 1994; Gonçalves Junior \& Callisto, 2013).

Organic matter that is present in the water from the riparian zone has long been studied in a fragmented way as food webs and energy flow, and can reveal patterns and generate ecological benefits (Tank et al., 2010). These studies have demonstrated that changes in riparian conditions result in dynamic variations in the aquatic fauna (Angermeier \& Karr, 1994; Gonçalves Junior et al., 2012), stream metabolic processes, and organic matter (Campbell et al., 1992; Webster et al., 1995; Sponseller \& Benfield, 2001). In addition, removal of the vegetation has negative consequences on growth rates, abundance and the invertebrate community trophic structure (Chakona et al., 2009; Chadwick et al., 2012; Suga \& Tanaka, 2013; Ferreira et al., 2015). In addition, changes in riparian vegetation affect the typical fragmentary distribution and decomposition of allochthonous organic matter (Sponseller \& Benfield, 2001; Encalada et al., 2010).

However, in recent years, some studies have shown that land use in the drainage area of aquatic environments also generates significant effects on aquatic communities. Changes in land use at different landscape scales alter the structure and composition of aquatic communities (Sensolo et al.,
2012; Valle et al., 2013; De Toni et al., 2014). Although the attention of the scientific community to be directed to the riparian zone of the streams, the presence and amount of vegetation in the drainage areas of these environments is important for the maintenance of environmental integrity, as well as providing conditions for the establishment and colonization of benthic macroinvertebrates (Oliveira et al., 2014). Thus, in this study, we evaluated the modifications in the land-use of streams drainage areas and the relationship with the taxonomic and functional feeding composition of aquatic invertebrate communities associated with leaf detritus. We tested the hypotheses that drainage area with less percentage of vegetation and absence of the riparian vegetation influences the composition of invertebrate fauna in detritus, resulting in a low variability of the community.

\section{Material and Methods}

\subsection{Study area}

We conducted this study in four small streams $(<3$ rd order) distributed in hydrographic sub-basin of Campo river (C) and hydrographic sub-basin of Cravo river $(\mathrm{Cr})$ in southern Brazil (Figure 1). The climate is subtropical with a regular rainfall regime and well-defined annual seasons. The annual mean temperature is $17.6^{\circ} \mathrm{C}$ and rainfall is well distributed throughout the year (range: 1750-2000 mm, annual mean: $1912 \mathrm{~mm}$ ). The vegetation is characterized by a mixture of Subtropical Forest of the Alto Uruguay and Mixed Rain Forest (Oliveira-Filho et al., 2015). The predominant land use is agricultural practices $(-77 \%$ of the area) and only $15 \%$ of the region area contains native vegetation (Decian et al., 2009).

We selected two streams with riparian vegetation $(\mathrm{V})$ in the adjacent area and two streams without riparian vegetation (WV) at drainage area. We used the riparian vegetation in the buffer zone as categorical variable. In addition, two streams (one with and other without riparian vegetation) are located in the same hydrographic sub-basin. In this form, we have four streams, two riparian vegetation situations, and two hydrographic sub-basins.

\subsection{Field experiment}

We used senescent leaves of Campomanesia xanthocarpa O. Berg (Myrtaceae). This species is native and occurs frequently in the riparian zone of streams in the forest formations in southern Brazil (Oliveira-Filho et al., 2006). We dried the leaves at environmental temperature $\left(-25^{\circ} \mathrm{C} / 5\right.$ days $)$. 


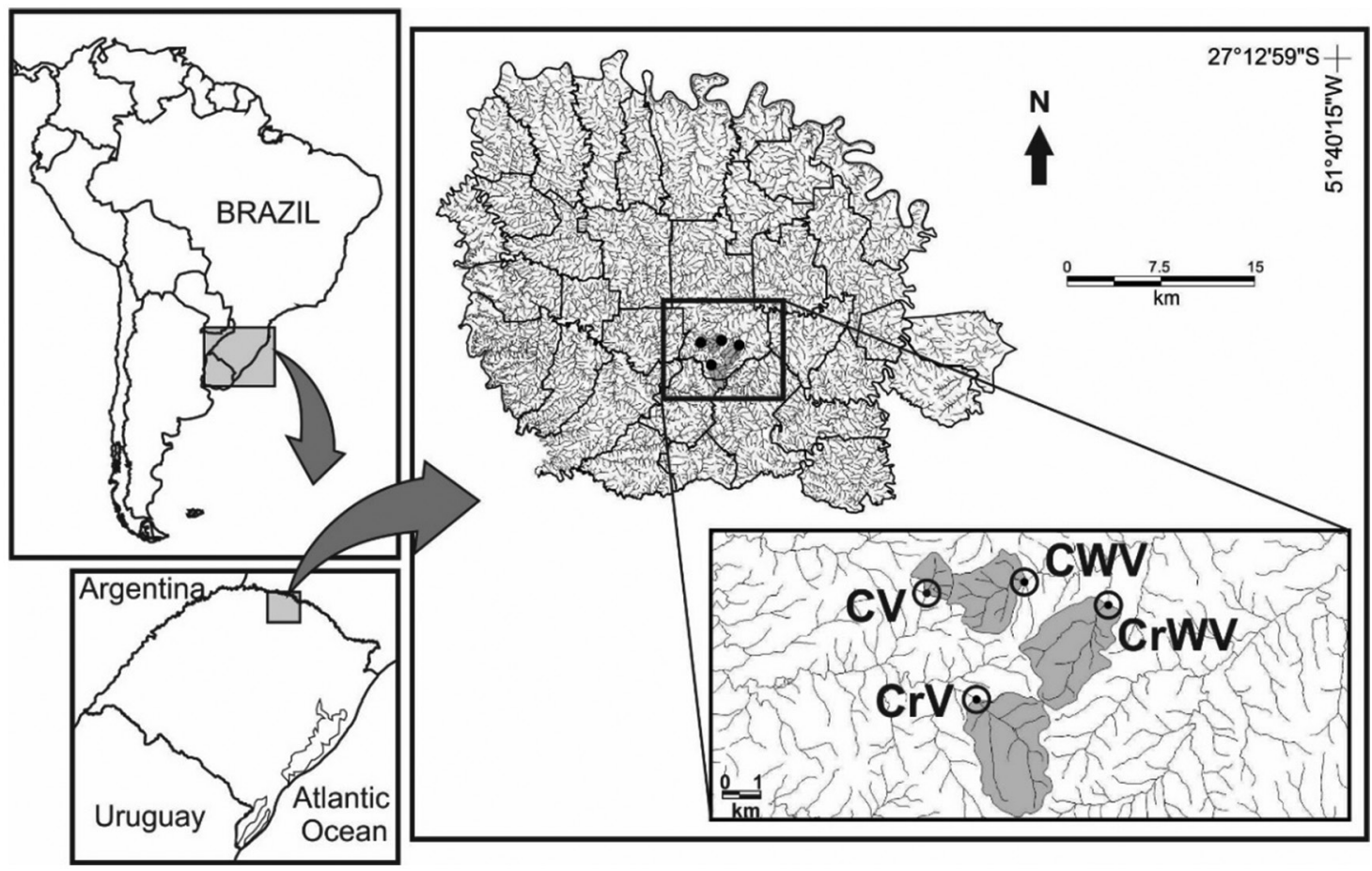

Figure 1. Localization of the streams in the Campo river hydrographic sub-basin and Cravo river hydrographic sub-basin, Southern Brazil.

The senescent leaves of C. xanthocarpa contain $2 \%$ of nitrogen, $0.04 \%$ of phosphorous, $4.5 \%$ of tannin and have a C:N ratio $=23$ (see details in Tonin et al., 2014).

We conducted the experiment in August 2010. We weighed $2.5 \pm 0.1 \mathrm{~g}$ leaves of $C$. xanthocarpa and added them to litter bags $(15 \times 20 \mathrm{~cm}, 10 \mathrm{~mm}$ mesh $)$. We incubated the litter bags in low current areas in the streams, randomly, and after 7, 14 and 21 days of leaf immersion, we removed four litter bags from each stream. We stored the litter bags in a thermic cooler, and in the laboratory, washed the debris to remove the associated invertebrates. We used a total of 48 litter bags in this study.

\subsection{Associated invertebrate fauna}

In the laboratory, we gently washed the leaves in running water through a sieve $(250 \mu \mathrm{m}$ mesh $)$ for invertebrate retention. We dried the material remaining in an oven at $40{ }^{\circ} \mathrm{C} / 72 \mathrm{~h}$, and weighed it to determine the mass loss. We identified the benthic invertebrates associated with the detritus to the lowest possible taxonomic level according to Merritt \& Cummins (1996), Fernandez \& Domingues (2001) and Mugnai et al. (2010). The classification of functional feeding groups was performed following the recommendations of Merritt \& Cummins (1996), Fernandez \& Domingues (2001), Kennet et al. (2005).

We excluded chironomid larvae from the analysis and the interpretation of results because they constitute a very abundant group in leaf litter decomposition (Ligeiro et al., 2010; Biasi et al., 2013). In additon, they perform an unclear ecological function in debris and have contained functional feeding groups (Sanseverino \& Nessimian, 2008; Tonin et al., 2014).

\subsection{Landscape and limnological variables}

We analyzed the landscape using geoprocessing techniques. The base map was adapted to work at $1: 35,000$, with a spatial distribution of $1 \times 1 \mathrm{~m}$, which were demarcated as catchment areas using the Triangle Irregular Network method. The classification of land use followed the method of rating Supervised Maximum Likelihood (maxlike). The ratings that fell within the area where the study was performed were: agriculture, exposed soil, pasture, and vegetation. We used MapInfo 8.5 and Idrisi 32 software.

We measured limnological variables in situ and collected water samples for laboratory analysis. The water variables measured in situ were: water temperature, dissolved oxygen, $\mathrm{pH}$, conductivity 
and turbidity and total dissolved solids, using a multiparameter Horiba ${ }^{\circledR}$ U-50PC analyzer. The variables measured $e x$ situ were alkalinity via an acid-based titration, and total organic carbon and total nitrogen were measured using a TOC Analyzer Shimadzu ${ }^{\circledR}$.

\subsection{Data analysis}

We evaluated the leaf mass loss during the study period as the decomposition rate $(\mathrm{k})$ by adjusting the values of the remaining dry weight by the negative exponential model $\mathrm{W}_{\mathrm{t}}=\mathrm{W}_{0} \cdot \mathrm{e}^{-\mathrm{kt}}$, where $\mathrm{Wt}$ is the weight at time $\mathrm{t}$ (in days), $\mathrm{W}_{0}$ is the initial weight and $\mathrm{k}$ is the decomposition coefficient (Webster \& Benfield, 1986). We used an analysis of variance (two way ANOVA) to assess the differences between sample days during the study period, and the effect of vegetation on the decomposition rate. To explore the taxonomic data and functional similarity community composition, we used a non-Metric Multidimensional Scaling (NMDS) analysis, using the Bray-Curtis dissimilarity coefficient. The NMDS was performed with a biological matrix based on presence/absence data using the Jaccard index. We used a multivariate analysis of variance (PerMANOVA, 999 permutations) to assess taxonomic and functional similarity of community composition differences between incubation days and streams. We tested the environmental data and biological matrix (NMDS) relationship by multivariate non-parametric correlation (function 'envfit'). For all analyses, we used a significance level equal to $\mathrm{p}<0.05$. We used the R software (R Development Core Team, 2013) with the 'vegan' package (Okansen et al., 2013).

\section{Results}

\subsection{Landscape and limnological variables}

During the experimental period, the water in the Campo river hydrographic basin streams (CV and CWV) showed a temperature of $15.3 \pm 0.9^{\circ} \mathrm{C}($ mean $\pm \mathrm{SD})$, was well oxygenated $(7.9 \pm 12.4 \mathrm{mg} / \mathrm{L})$, and slightly acidic $(\mathrm{pH} 6.5 \pm 0.3)$ (Table 1). Similarly, the streams in the Cravo river hydrographic basin ( $\mathrm{CrV}$ and $\mathrm{CrWV}$ ) had water with a temperature of $17.1 \pm 0.3{ }^{\circ} \mathrm{C}$, which was well oxygenated $(8.0 \pm 0.9 \mathrm{mg} / \mathrm{L})$ and slightly acidic ( $\mathrm{pH} 6.7 \pm 0.2$ ). The limnological variables of the four streams were similar, when the hydrographic basins and the presence of riparian vegetation were compared (Table 2).

In general, in the Campo river hydrographic basin, the main land uses in the drainage area were exposed soil (23.8\%), pasture (30.5\%), agriculture (36.9\%), and vegetation (8.6\%) (Table 1). The main land uses in the Cravo river hydrographic basin were exposed soil (30.2\%), pasture (34\%), agriculture (23.7\%), and vegetation (12\%) (Table 1). The land use varied between hydrographic basins and the presence of riparian vegetation (Table 2).

\subsection{Leaf mass loss of C. xanthocarpa and associated invertebrate fauna}

At the end of the study period, the higher mass loss of $C$. xanthocarpa was observed in riparian vegetation streams in the Cravo river hydrographic

Table 1. Limnological variables (mean \pm SD) and land uses (\%) of the streams in the Campo river hydrographic sub-basin and Cravo river hydrographic sub-basin, Southern Brazil.

\begin{tabular}{|c|c|c|c|c|}
\hline \multirow[t]{2}{*}{ Variables } & \multicolumn{4}{|c|}{ Streams } \\
\hline & CV & CWV & $\mathrm{CrV}$ & CrWV \\
\hline Geographic Coordenates & $\begin{array}{l}27^{\circ} 42^{\prime} 58^{\prime \prime} \mathrm{S} \\
52^{\circ} 14^{\prime} 43^{\prime \prime} \mathrm{W}\end{array}$ & $\begin{array}{l}27^{\circ} 43^{\prime} 28^{\prime \prime} \mathrm{S} \\
52^{\circ} 12^{\prime} 43^{\prime \prime} \mathrm{W}\end{array}$ & $\begin{array}{l}27^{\circ} 43^{\prime} 13^{\prime \prime} \mathrm{S} \\
52^{\circ} 17^{\prime} 11^{\prime \prime} \mathrm{W}\end{array}$ & $\begin{array}{l}27^{\circ} 45^{\prime} 37^{\prime \prime} \mathrm{S} \\
52^{\circ} 15^{\prime} 57^{\prime \prime} \mathrm{W}\end{array}$ \\
\hline Water temperature $\left({ }^{\circ} \mathrm{C}\right)$ & $14.2 \pm 0.5$ & $16,1 \pm 0.2$ & $17.4 \pm 0.6$ & $18.1 \pm 0.8$ \\
\hline $\mathrm{pH}$ & $6.4 \pm 0.5$ & $6.9 \pm 0.3$ & $6.4 \pm 0.3$ & $6.3 \pm 0.5$ \\
\hline Total dissolved solids (mg/L) & $0.033 \pm 0.001$ & $0.048 \pm 0.001$ & $0.025 \pm 0.001$ & $0.040 \pm 0.001$ \\
\hline Dissolved Oxygen (mg/L) & $7.9 \pm 0.7$ & $6.5 \pm 1.3$ & $6.5 \pm 0.8$ & $8.6 \pm 0.3$ \\
\hline Conductivity $(\mu \mathrm{S} / \mathrm{cm})$ & $166 \pm 20$ & $74 \pm 9$ & $38 \pm 8$ & $198 \pm 20$ \\
\hline Alkalinity (mg/L) & $1.8 \pm 0.1$ & $2.5 \pm 0.1$ & $1.1 \pm 0.1$ & $1.9 \pm 0.1$ \\
\hline Total organic carbon (mg/L) & 16.7 & 17.1 & 4.2 & 25.6 \\
\hline Total nitrogen (mg/L) & $1.71 \pm 0.02$ & $2.92 \pm 0.05$ & $1.57 \pm 0.01$ & $1.76 \pm 0.01$ \\
\hline Drainage area (ha) & 668.3 & 1073.2 & 199.4 & 1284.8 \\
\hline Slope (\%) & 16.5 & 14.6 & 12.2 & 16.9 \\
\hline Agriculture (\%) & 32.8 & 28.6 & 38.3 & 29.3 \\
\hline Expouse soil (\%) & 10.4 & 20.9 & 35.7 & 31.6 \\
\hline Pasture (\%) & 42.5 & 39.0 & 5.3 & 24.4 \\
\hline Vegetation (\%) & 14.4 & 11.5 & 20.7 & 14.8 \\
\hline
\end{tabular}


Table 2. PerMANOVA results of the environmental variables (limnological and land uses) and taxonomic and functional composition invertebrate fauna in the Campo river hydrographic basin and Cravo river hydrographic basin, Southern Brazil.

\begin{tabular}{|c|c|c|c|c|c|}
\hline & df & SS & MS & F-value & p-value \\
\hline \multicolumn{6}{|l|}{ Limnological variables } \\
\hline Sub-basins & 1 & 0.069 & 0.069 & 1.289 & 0.255 \\
\hline Presence of Vegetation & 1 & 0.050 & 0.050 & 0.941 & 0.374 \\
\hline Residuals & 9 & 0.485 & 0.053 & & \\
\hline \multicolumn{6}{|l|}{ Land use variables } \\
\hline Sub-basins & 1 & 0.036 & 0.036 & 9.316 & 0.018 \\
\hline Presence of Vegetation & 1 & 0.204 & 0.204 & 52.596 & 0.001 \\
\hline Residuals & 9 & 0.034 & 0.004 & & \\
\hline \multicolumn{6}{|c|}{ Invertebrates taxonomic composition } \\
\hline Sub-basins & 1 & 0.317 & 0.317 & 6.621 & 0.001 \\
\hline Presence of Vegetation & 1 & 0.864 & 0.864 & 18.004 & 0.001 \\
\hline Time & 1 & 0.041 & 0.041 & 0.868 & 0.468 \\
\hline Residuals & 44 & 2.112 & 0.048 & & \\
\hline \multicolumn{6}{|c|}{ Invertebrates functional feeding group composition } \\
\hline Sub-basins & 1 & 0.216 & 0.216 & 2.282 & 0.069 \\
\hline Presence of Vegetation & 1 & 1.713 & 1.713 & 18.069 & 0.001 \\
\hline Time & 1 & 0.044 & 0.044 & 0.468 & 0.729 \\
\hline Residuals & 44 & 4.171 & 0.948 & & \\
\hline
\end{tabular}

basin (Figure 2). The percentage residual leaf weight in the Campo river was lower in the stream with riparian vegetation $(80.4 \%$ of the remaining weight; $\mathrm{k}=-0.0148 \mathrm{~g} /$ day). In contrast, leaves in the stream without riparian vegetation showed the lowest residual weight $(71.1 \%$; $=-0.0229 \mathrm{~g} /$ day; Figure 2). Leaves from both streams of the Cravo river hydrographic basin showed a similar residual weight $(77.4 \%, \mathrm{k}=-0.0179 \mathrm{~g} /$ day; $77 \%, \mathrm{k}=-0.0181 \mathrm{~g} /$ day; Figure 2).

During the experimental period, 2674 invertebrates were collected (Table 3). Of the total, 363 individuals were collected in the stream of the Campo river with riparian vegetation (density $=16 \mathrm{ind} / \mathrm{g} \mathrm{DW}$ ), and 713 individuals in the stream without vegetation (30 ind/g DW). In the Cravo river basin, 315 individuals were collected in the stream with riparian vegetation ( $9 \mathrm{ind} / \mathrm{g} \mathrm{DW})$ and 1,195 individuals in the stream without vegetation (62 ind/g DW). The most frequent functional feeding group (FFG) was scrapers $(62 \%)$, followed by filterers (18.8\%), shredders (15\%), collectors $(4.1 \%)$, and predators $(0.1 \%)$. Moreover, there were a higher percentage of shredders in the two riparian vegetation streams.

The NMDS ordination showed segregation in taxonomic and functional feeding-group composition among streams with and without vegetation (Figure 3). The invertebrate taxonomic composition was different in the hydrographic basins and in the presence of riparian vegetation

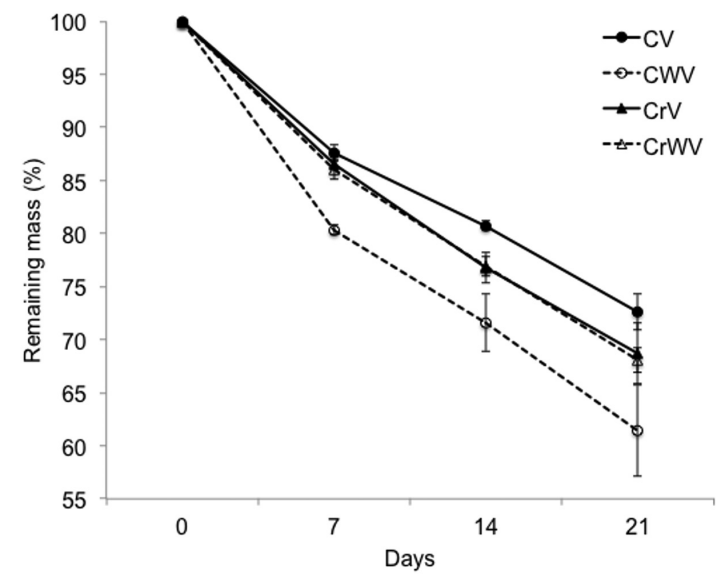

Figure 2. Remaining mass ( \pm SE) of Campomanesia xanthocarpa leaf litter in the streams in the Campo river hydrographic basin and Cravo river hydrographic basin, Southern Brazil.

(Table 2). Moreover, the functional feeding-group composition differed only in the presence of riparian vegetation (Table 2 ). The sampling unit ordination of taxonomic composition was correlated with vegetation $(\mathrm{r}=0.94, \mathrm{p}=0.001)$ and anthropogenic uses $(\mathrm{r}=-0.94, \mathrm{p}=0.001)$, water temperature $(\mathrm{r}=0.88, \mathrm{p}=0.007)$, and total organic carbon $(\mathrm{r}=-0.72, \mathrm{p}=0.002)$. On the other hand, FFG composition only correlated with electrical conductivity $(\mathrm{r}=-0.99, \mathrm{p}=0.05)$. 
Table 3. Invertebrates abundance and functional feeding group (FFG) associated in Campomanesia xanthocarpa in the Campo river hydrographic basin and Cravo river hydrographic basin, Southern Brazil.

\begin{tabular}{|c|c|c|c|c|c|}
\hline \multirow[t]{2}{*}{ Taxa } & \multirow[t]{2}{*}{ FFG } & \multicolumn{2}{|c|}{ Campo river } & \multicolumn{2}{|c|}{ Cravo river } \\
\hline & & $\mathbf{V}$ & WV & $\mathbf{V}$ & WV \\
\hline Simuliidae & Filterer & 15 & 156 & 129 & 186 \\
\hline Caenidae & Scraper & 0 & 0 & 0 & 7 \\
\hline Baetidae & Scraper & 130 & 327 & 8 & 94 \\
\hline Leptohyphidae & Scraper & 5 & 0 & 0 & 0 \\
\hline Leptophlebiidae & Scraper & 2 & 4 & 0 & 37 \\
\hline Gripopterygidae & Collector/Shredder & 166 & 13 & 69 & 119 \\
\hline Hydropsychidae & Scraper & 37 & 204 & 101 & 641 \\
\hline Hydroptilidae & Collector/Scraper & 3 & 4 & 3 & 96 \\
\hline Glossosomatidae & Scraper & 0 & 0 & 0 & 1 \\
\hline Odontoceridae & Scraper & 0 & 0 & 0 & 1 \\
\hline Elmidae & Collector/Shredder & 3 & 3 & 2 & 12 \\
\hline Psephenidae & Scraper & 0 & 1 & 0 & 0 \\
\hline Calopterigidae & Predator & 0 & 1 & 1 & 1 \\
\hline Hydrobiidae & Scraper & 2 & 0 & 1 & 0 \\
\hline Ancilidae & Scraper & 0 & 0 & 1 & 0 \\
\hline
\end{tabular}

V: wich vegetation; WV: without vegetation.
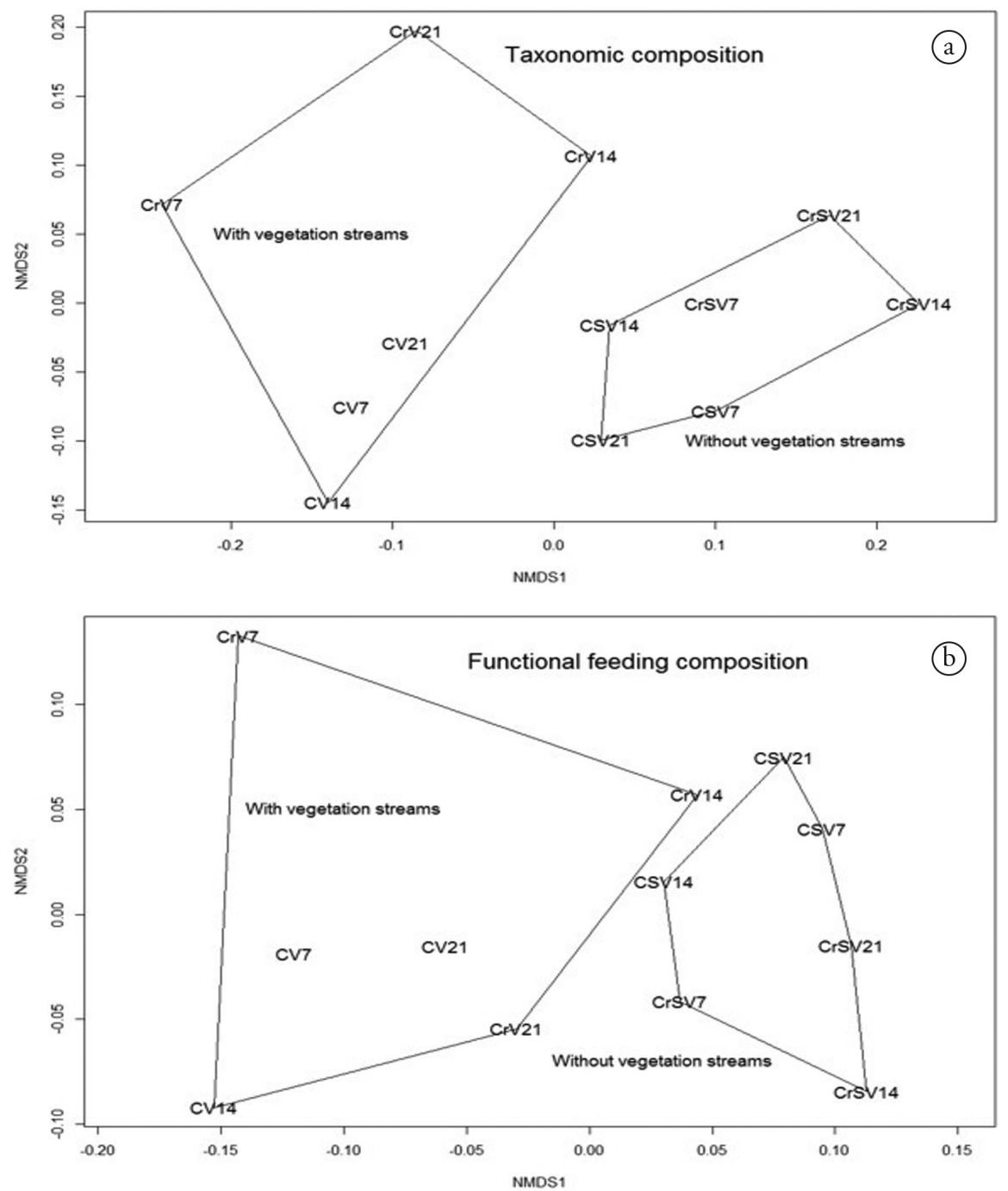

Figure 3. NMDS ordination of (a) taxonomic and (b) functional invertebrate fauna composition associated in Campomanesia xanthocarpa leaf litter in the streams in the Campo river hydrographic sub-basin and Cravo river hydrographic sub-basin, Southern Brazil. 


\section{Discussion}

The limnological variables were similar among streams, although the land use varied between the streams in the two hydrographic basins. As expected, the riparian vegetation of the streams was the determining factor for this difference. Land uses affect the river basin characteristics, and alter the hydrological characteristics, substrate availability, water quality, and aquatic biota (Smith \& Lamp, 2008). Changes in landuse (e.g., agricultural and pasture) have dramatically impacted aquatic ecosystems and are the major cause of riparian zone deforestation (Harding et al., 2006; Sensolo et al., 2012), with the low slope in both hydrographic basins favours agricultural landuse.

The leaves of $C$. xanthocarpa used in the litter bags experiments have a low nutritional quality (Tonin et al., 2014) and are essential to understand the effect of the riparian vegetation presence on the taxonomic and functional composition of the invertebrate community. The input of allochthonous organic matter into the stream increases the environmental heterogeneity, and provides a refuge and food source for aquatic biota (Biasi et al., 2013; König et al., 2014). However, in this study, we believe that the litter bags acted specifically as a refuge, because of the lower density of shredders than in the streams with vegetation. The removal of the riparian vegetation caused a reduction in the density of shredders in this study. Shredders are clearly very important in the transformation process of organic matter in forested and deforested streams (Masese et al., 2014).

The taxonomic composition of the invertebrate communities was more sensitive to variation in the streams. The change in land use (e.g., the removal of vegetation and increase in agricultural area) causes variations in community composition by excluding some less sensitive taxa (Sensolo et al., 2012). The water temperature and total organic carbon are influenced by agricultural activity. The replacement of vegetation by agriculture decreases the canopy and favours light penetration and an increase in water temperature. On the other hand, the higher sediment input contributes to an increase in the nutrients and organic matter concentration in streams (Nava et al., 2015), which might affect the availability of food (e.g., biofilm). Thus, the main carbon source for organisms becomes autochthonous instead allochthonous. This change in food for the benthic community decreases the shredder density and increases the density of scrapers.
Biological factors are important during the decomposition process and relate to colonisation by fungi, bacteria and invertebrates (Abelho, 2001). Microrganisms are responsible for conditioning the detritus, and make organic matter more palatable to invertebrates due to the degradation of refractory compounds (Bärlocher, 1992; Graça \& Cressa, 2010). In this study, the experimental period might not have been favourable for colonisation by microorganisms such as shredders. Some studies have reported the importance of incubation time on the fragmentation of debris (Ligeiro et al., 2010; Biasi et al., 2013), which is essential for microbial conditioning, to accelerate the decomposition process (Encalada et al., 2010). In this study, these arguments are relevant, since the higher abundance of shredders is not reflected in the mass loss of detritus. Therefore, this mass loss might have been caused by the action of the stream, but the debris also constitutes a habitat that is extremely favorable to invertebrates. Furthermore, the additive effects of nutrients and/or shredder organisms on litter processing rates can be confounded by others factors (Huryn et al., 2002).

The remaning percentage of detritus mass in the streams did not affect the presence of riparian vegetation. In the Campo river hydrographic basin, leaves in the two streams had similar loss in mass, whereas in the Cravo river hydrographic basins, leaves in the stream without vegetation showed a lower residual mass. Among the many factors that might contribute to loss in mass of debris, water physico-chemical characteristics and leaf chemicals are the factors that affect the leaf leaching process. However, although the same plant species was used and the streams were limnologically similars, the most plausible explanation for the mass loss of debris is the flow action of the streams; water flow increases the mass loss, due to the removal of soluble compounds by leaching. In addition, flow stress the fibers that comprise the leaf structure and increases the leaching of compounds (Fonseca et al., 2013). The decomposition rates observed in this study can be considered to be rapid ( $k>-0.0173$ ), except for those of incubated debris in the stream without vegetation in the Campo river hydrographic basin, whose coefficient of decomposition is considered to be intermediate $(-0.0041>\mathrm{k}<-0.0173)$ according to the classification proposed by Gonçalves et al. (2013).

The presence of riparian vegetation was essencial to modify the taxonomic and functional invertebrate composition. In this study, the density of shredders 
was lower in the streams without vegetation. This is important when considering the drainage areas of small streams in areas with intensive agricultural practice. In small streams, the main source of energy is allochthonous material (Gonçalves Junior \& Callisto, 2013). In addition, shredders are responsible for transforming course particulate organic matter to fine particulate organic matter (Vannote et al., 1980). Thus, nutrient cycling, especially that of carbon, is complex in streams that are under the influence of agriculture. Finally, this study showed that the riparian vegetation has an importance in the structure of invertebrate communities, but the land uses in drenage basin streams should be considered. The intensive occupation of the small streams drainage basin can cause serious changes on aquatic biota. A fragile riparian zone not support a high anthropogenic pressure from adjacent areas. Our study contributes to information for managers. The managers should to observe, not only the riparian zone of lotic environments conditions, but all land uses of the watershed.

\section{Acknowledgements}

LUH received financial support from $\mathrm{CNPq}$ (Process \#471572/2012-8). FMU, RCL received scholarship from PROSUP/CAPES. GT received scholarship from FAPERGS.

\section{References}

ABELHO, M. From litterfall to breakdown in streams: a review. The Scientific World Journal, 2001, 1(2001), 656-680. http://dx.doi.org/10.1100/tsw.2001.103. PMid:12805769.

ALLAN, J.D. Landscapes and riverscapes: the influence of land use on stream ecosystems. Annual Review of Ecology Evolution and Systematics, 2004, 35(1), 257-284. http://dx.doi.org/10.1146/annurev. ecolsys.35.120202.110122.

ANGERMEIER, P.L. and KARR, J.R. Biological integrity versus diversity as policy directives protecting biotic resources. Bioscience Journal, 1994, 44(10), 690-697. http://dx.doi.org/10.2307/1312512.

ARNAIZ, O.L., WILSON, A.L., WATTS, R.J. and STEVENS, M.M. Influence of riparian condition on aquatic macroinvertebrate communities in an agricultural catchment in South-Eastern Australia. Ecological Research, 2011, 26(1), 123-131. http:// dx.doi.org/10.1007/s11284-010-0767-2.

BÄRLOCHER, F. Community organization. In F. BÄRLOCHER, ed. The Ecology of aquatic hyphomycetes. Berlin: Springer-Verlag, 1992, 225 p.
BIASI, C., TONIN, A.M., RESTELLO, R.M. and HEPP, L.U. The colonisation of leaf litter by Chironomidae (Diptera): The influence of chemical quality and exposure duration in a subtropical stream. Limnologica, 2013, 43(6), 427-433. http://dx.doi. org/10.1016/j.limno.2013.01.006.

BLEVINS, Z.W., EFFERT, E.L., WAHL, D.H. and SUSKI, C.D. Land use drives the physiological properties of a stream fish. Ecological Indicators, 2013, 24, 224-235. http://dx.doi.org/10.1016/j. ecolind.2012.06.016.

BONATO, K.O., DELARIVA, R.L. and SILVA, J.C. Diet and trophic guilds of fish assemblages in two streams with different anthropic impacts in the northwest of Paraná, Brazil. Zoologia, 2012, 29(1), 27-38. http://dx.doi.org/10.1590/S198446702012000100004 .

CAMPBELL, I.C., JAMES, K.R., HART, B.T. and DEVEREAUX, A. Allochthonous coarse particulate organic material in forest and pasture reaches of two South-Eastern Australian streams. Freshwater Biology, 1992, 27(3), 353-365. http://dx.doi. org/10.1111/j.1365-2427.1992.tb00545.x.

CARVALHO, F.M.V., MARCO, P.D.E. and FERREIRA, L.G. The Cerrado into-pieces: Habitat fragmentation as a function of landscape use in the savannas of central Brazil. Biological Conservation, 2009 142(7), 1392-1403. http://dx.doi.org/10.1016/j. biocon.2009.01.031.

CHADWICK, M.A., THIELE, J.E., HURYN, A.D., BENKE, A.C. and DOBBERFUHL, D.R. Effects of urbanization on macroinvertebrates in tributaries of the St. Johns River, Florida, USA. Urban Ecosystems, 2012, 15(2), 347-365. http://dx.doi.org/10.1007/ s11252-011-0217-0.

CHAKONA, A., PHIRI, C., CHINAMARINGA, T. and MULLER, N. Changes in biota along a dryland river in northwestern Zimbabwe: declines and improvements in river health related to land use. Aquatic Ecology, 2009, 43(4), 1095-1106. http:// dx.doi.org/10.1007/s10452-008-9222-7.

DE TONI, K.R., NAVA, D., RESTELLO, R.M., DECIAN, V., ROVANI, I.L. and HEPP, L.U. Integridade da paisagem e sua influência sobre a composição da comunidade de Chironomidae (Diptera) em riachos de pequena ordem. Ecología Austral, 2014, 24, 335-342.

DECIAN, V.S., ZANIN, E.M., OLIVEIRA, C.H., QUADROS, F.R. and FERRARI, C.A. Uso da terra na região Alto Uruguai do Rio Grande do Sul e obtenção de banco de dados relacional de fragmentos de vegetação arbórea. Perspectiva, 2009, 33(121), $165-176$.

DINIZ-FILHO, J.A.F., OLIVEIRA, L.G., LOBO, F., FERREIRA, L.G., BINI, L.M. and RANGEL, T.F.L.B. Agriculture, habitat loss and spatial patterns of human occupation in a biodiversity hotspot. 
Scientia Agricola, 2009, 66(6), 764-771. http:// dx.doi.org/10.1590/S0103-90162009000600007.

ENCALADA, A.C., CALlES, J., FERREIRA, V., CANHOTO, C.M. and GRAÇA, M.A.S. Riparian land use and the relationship between the benthos and litter decomposition in tropical montane streams. Freshwater Biology, 2010, 55, 1719-1733. http:// dx.doi.org/10.1111/j.1365-2427.2010.02406.x

FERNANDEZ, H.R. and DOMINGUES, E. Guia para la determinación de los artrópodos bentónicos sudamericanos. Tucumán: UNT, 2001.

FERREIRA, W.R., LIGEIRO, R., MACEDO, D.R., HUGHES, R.M., KAUFMANN, P.R., OLIVEIRA, L.G. and CALLISTO, M. Is the diet of a typical shredder related to the physical habitat of headwater streams in the Brazilian Cerrado? Annales de Limnologie. International Journal of Limnology, 2015, 51(2), 115-124. http://dx.doi.org/10.1051/ $\operatorname{limn} / 2015004$.

FONSECA, A.L.S., BIANCHINI, I., PIMENTA, C.M.M., SOARES, C.B.P. and MANGIAVACCHI, $\mathrm{N}$. The flow velocity as driving force for decomposition of leaves and twigs. Hydrobiologia, 2013, 703(1), 5967. http://dx.doi.org/10.1007/s10750-012-1342-3.

GONÇALVES JUNIOR, J.F. and CALLISTO, M. Organic-matter dynamics in the riparian zone of a tropical headwater stream in Southern Brazil. Aquatic Botany, 2013, 109, 8-13. http://dx.doi. org/10.1016/j.aquabot.2013.03.005.

GONÇALVES JUNIOR, J.F.J., REZENDE, R.S., MARTINS, N.M. and GREGÓRIO, R.S. Leaf breakdown in an Atlantic Rain Forest stream. Austral Ecology, 2012, 37(7), 807-815. http://dx.doi. org/10.1111/j.1442-9993.2011.02341.x.

GONÇALVES, J.F., MARTINS, R.T., OTTONI, B.M.P. and COUCEIRO, C.R.M. Visão sobre a decomposição foliar em sistemas aquáticos brasileiros. In N. HAMADA, J.L. NESSIMIAN and R.B. QUERINO, eds. Insetos aquáticos na biologia e ecologia. Manaus: INPA, 2013, pp. 89-116.

GRAÇA, M.A.S. and CRESSA, C. Leaf quality of some tropical and temperate tree species as food resource for stream shredders. International Review of Hydrobiology, 2010, 95(1), 27-41. http://dx.doi. org/10.1002/iroh.200911173.

HAGEN, E.M., WEBSTER, J.R. and BENFIELD, E.F. Are leaf breakdown rates a useful measure of stream integrity along an agricultural land use gradient? Journal of the North American Benthological Society, 2006, 25(2), 330-343. http://dx.doi. org/10.1899/0887-3593(2006)25[330:ALBRAU] 2.0.CO;2.

HARDING, J.S., CLAASSEN, K. and EVERS, N. Can forest fragments reset physical and water quality conditions in agricultural catchments and act as refugia for forest stream invertebrates? Hydrobiologia,
2006, 568(1), 391-402. http://dx.doi.org/10.1007/ s10750-006-0206-0.

HENRY, R., UIEDA, V.S., AFONSO, A.A. and KIKUCHI, R.M. Input of allochthonous matter and structure of fauna in a Brazilian headstream. Verhandlungen der Internationalen Vereinigung für Theoretische und Angewandte Limnologie, 1994, 25, 1866-1870.

HURYN, A.D., HURYN, V.M., ARBUCKLE, C.J. and TSOMIDES, L. Catchment land use, macroinvertebrates and detritus processing in headwater streams: taxonomic richness versus function. Freshwater Biology, 2002, 47(3), 401-415. http://dx.doi.org/10.1046/j.13652427.2002.00812.x.

KENNET, W., CUMMINS, K.W., MERRITT, R.W. and ANDRADE, P.C.N. The use of invertebrate functional groups to characterize ecosystem attributes in selected streams and rivers in south Brazil. Studies on Neotropical Fauna and Environment, 2005, 40(1), 69-89. http://dx.doi. org/10.1080/01650520400025720.

KLAPPROTH, J.C. and JOHNSON, J.E. Understanding the science behind riparian forest buffers: effects on water quality. Virgínia: Virginia Cooperative Extension, Publication Virginia Polytechnic Institute and State University, 2000, pp. 420-451.

KÖNIG, R., HEPP, L.U. and SANTOS, S. Colonisation of low- and high-quality detritus by benthic macroinvertebrates during leaf breakdown in a subtropical stream. Limnologica, 2014, 45, 61-68. http://dx.doi.org/10.1016/j.limno.2013.11.001.

LIGEIRO, R., MORETTI, M.S., GONÇALVES, J.F. and CALLISTO, M. What is more important for invertebrate colonization in a stream with lowquality litter inputs: exposure time or leaf species? Hydrobiologia, 2010, 654(1), 125-136. http://dx.doi. org/10.1007/s10750-010-0375-8.

MASESE, F.O., KITAKA, N., KIPKEMBOI, J., GETTEL, G.M., IRVINE, K. and MCCLAIN, M.E. Litter processing and shredder distribution as indicators of riparian and catchment influences on ecological health of tropical streams. Ecological Indicators, 2014, 46, 23-37. http://dx.doi. org/10.1016/j.ecolind.2014.05.032.

MERRITT, R.W. and CUMMINS, K.V. An introduction to the aquatic insects of North America. Dubuque: Kendall/Hunt, 1996.

MUGNAI, R., NESSIMIAN, J.L. and BAPTISTA, D.F. Manual de identificação de macroinvertebrados aquáticos do Estado do Rio de Janeiro. Rio de Janeiro: Technical Books, 2010.

NAIMAN, R.J., DÉCAMPS, H. and MCCLAIN, M.E. Riparia: Ecology, conservation, and management of streamside communities. Cambridge: Academic Press, 2005. 
NAVA, D., RESTELLO, R.M. and HEPP, L.U. Intra- and inter-annual variations in Chironomidae (Insecta: Diptera) communities in subtropical streams. Zoologia, 2015, 32(3), 207-214. http:// dx.doi.org/ 10.1590/S1984-46702015000300005

OKANSEN, J., BLANCHET, F.G., KINDT, R., LEGENDRE, P., O'HARA, R.G., SIMPSON, G.L., SOLYMOS, P., STEVENS, M.H.H. and WAGENER, H. Vegan: Community Ecology Package: $R$ package version 1.17-0 [online]. 2013 [viewed 03 Feb. 2016]. Available from: http://CRAN.R-project. org/package=vegan .

OLIVEIRA, V.C., GONÇALVES, E.A. and ALVES, R.G. Colonisation of leaf litter by aquatic invertebrates in an Atlantic Forest stream. Brazilian Journal of Biology = Revista Brasileira de Biologia, 2014, 74(2), 267-273. http://dx.doi.org/10.1590/15196984.10512. PMid:25166310.

OLIVEIRA-FILHO, A.T., BUDKE, J.C., JARENKOW, J.A., EISENLOHR, P.V. and NEVES, D.R.M. Delving into the variations in tree species composition and richness across South American subtropical Atlantic and Pampean forests. Journal of Plant Ecology, 2015, 8(3), 242-260. http://dx.doi. org/10.1093/jpe/rtt058.

OLIVEIRA-FILHO, A.T., JARENKOW, J.A. and RODAL, M.J.N. Floristic relationships of seasonally dry forests of eastern South America based on tree species distribution patterns. In R.T. PENNINGTON, G.P. LEWIS and J.A. RATTER, eds. Neotropical Savannas and seasonally dry forests: plant diversity, biogeography, and conservation. Boca Raton: CRC Press, 2006, pp. 159-192.

R DEVELOPMENT CORE TEAM. $R$ : a language and environment for statistical computing [online]. Vienna: R Foundation for Statistical Computing, 2013. [viewed 03 Feb. 2016]. Available from http:// www.R-project.org.

SANSEVERINO, A.M. and NESSIMIAN, J.L. Larvas de Chironomidae (Diptera) em depósitos de folhiço submerso em um riacho de primeira ordem da Mata Atlântica (Rio de Janeiro, Brasil). Revista Brasileira de Entomologia, 2008, 52(1), 95-104. http://dx.doi. org/10.1590/S0085-56262008000100017

SENSOLO, D., HEPP, L.U., DECIAN, V.S. and RESTELLO, R.M. Influence of landscape on the assemblages of Chironomidae in Neotropical streams. Annales de Limnologie. International Journal of Limnology, 2012, 48(4), 391-400. http://dx.doi. org/10.1051/limn/2012031.

SMITH, R.F. and LAMP, W.O. Comparison of insect communities between adjacent headwater and main- stem stream in urban and rural watersheds. Journal of the North American Benthological Society, 2008, 27(1), 161-175. http://dx.doi.org/10.1899/07-071.1.

SPONSELLER, R.A. and BENFIELD, E.F. Influences of land use breakdown in southern Appalachian headwater streams: a multiple-scale analysis. Journal of the North American Benthological Society, 2001, 20(1), 44-59. http://dx.doi.org/10.2307/1468187.

SUGA, C.M. and TANAKA, M.O. Influence of a forest remnant on macroinvertebrate communities in a degraded tropical stream. Hydrobiologia, 2013, 703(1), 203-213. http://dx.doi.org/10.1007/s10750012-1360-1.

TANK, J.L., ROSI-MARSHALL, E.J., GRIFFITHS, N.A., ENTREKIN, S.A. and STEPHEN, M.L. A review of allochthonous organic matter dynamics and metabolism in streams. Journal of the North American Benthological Society, 2010, 29(1), 118-146. http:// dx.doi.org/10.1899/08-170.1.

TONIN, A.M., HEPP, L.U., RESTELLO, R.M. and GONÇALVES, J.F. Understanding of colonization and breakdown of leaves by invertebrates in a tropical stream is enhanced by using biomass as well as count data. Hydrobiologia, 2014, 740(1), 79-88. http:// dx.doi.org/10.1007/s10750-014-1939-9.

VALLE, I.C., BUSS, D.F. and BAPTISTA, D.F. The influence of connectivity in forest patches, and riparian vegetation width on stream macroinvertebrate fauna. Brazilian Journal of Biology $=$ Revista Brasileira de Biologia, 2013, 73(2), 1-8. http://dx.doi.org/10.1590/ S1519-69842013000200002. PMid:23917549.

VANNOTE, R.L., MINSHALL, G.V., CUMMINS, K.W., SEDELL, J.R. and CUSHING, C.E. River Continuum Concept. Canadian Journal of Fisheries and Aquatic Sciences, 1980, 37(1), 130-137. http:// dx.doi.org/10.1139/f80-017.

WEBSTER, J. and BENFIELD, E.F. Vascular plant breakdown in freshwater ecosystems. Annual Review of Ecology and Systematics, 1986, 17(1), 567-594. http://dx.doi.org/10.1146/annurev. es.17.110186.003031.

WEBSTER, J.R., WALLACE, J.B. and BENFIELD, E.F. Organic processes in streams of the eastern United States. In C.E. CUSHING, K.W. CUMMINS and G.W. MINSHALL, eds. Ecosystems of the world: river and stream ecosystems. Amsterdan: Elsevier, 1995, pp. 117-187.

Received: 03 February 2016 Accepted: 04 May 2016 